\title{
PERSEPSI MAHASISWA FAKULTAS KEDOKTERAN UNIVERSITAS UDAYANA TERHADAP ORANG DENGAN HUMAN IMMUNODEFICIENCY VIRUS / ACQUIRED IMMUNE DEFICIENCY SYNDROME
}

\author{
Ni Kadek Putri Silvia Maha Dewwi, Made Pasek Kardiwinata* \\ Program Studi Sarjana Kesehatan Masyarakat, Fakultas Kedokteran, Universitas Udayana \\ *Email : pkardiwinata@gmail.com
}

\begin{abstract}
ABSTRAK
Persepsi adalah proses individu melakukan pengamatan melalui penginderaan terhadap objek tertentu yang kemudian diseleksi, diatur, serta diinterpretasikan untuk menciptakan suatu gambaran yang berarti. Persepsi yang negatif dapat berpengaruh terhadap sikap dan penerimaan seseorang yang dapat memunculkan stigma dan diskriminasi. Tujuan penelitian ini mengetahui persepsi mahasiswa Fakultas Kedokteran Universitas Udayana terhadap Orang dengan HIV/AIDS (ODHA). Penelitian ini menggunakan pendekatan kuantitatif dengan menggunakan design penelitian deskriptif dengan rancangan cross sectional pada 102 responden yang dipilih secara non-probability sampling yaitu accidental sampling. Hasil univariat penelitian ini menunjukan bahwa sebagian besar mahasiswa FK Unud berada pada tingkat persepsi negatif yaitu sebesar 52,94\%. Kemudian, variabel yang lebih besar proporsinya memiliki persepsi baik yaitu variabel jenis kelamin laki-laki, program studi kesehatan masyarakat, semester delapan, mahasiswa yang pernah berinteraksi dengan ODHA, mahasiswa yang pernah mengikuti organisasi terkait ODHA, dan mahasiswa yang memiliki status interaksi baik. Didapatkan juga bahwa tingkatan semester dan intensitas interaksi memiliki hubungan yang signifikat dengan persepsi mahasiswa terhadap ODHA. Oleh karena itu, disarankan bahwa pihak Fakultas Kedokteran maupun Program Studi menyediakan program peningkatan pengetahuan mahasiswa FK tentang HIV/AIDS dengan cara mengintegrasikan ke acara-acara mahasiswa untuk dapat meningkatkan persepsi mahasiswa terhadap pasien khususnya ODHA.
\end{abstract}

Kata Kunci: Persepsi, ODHA, Mahasiswa Fakultas Kedokteran.

\begin{abstract}
Perception is the process of individuals making observations through sensing of certain objects which are then selected, arranged, and interpreted to create a meaningful picture. A negative perception can affect a person's attitude and acceptance which can lead to stigma and discrimination. The purpose of this study was to determine the perceptions of Udayana University Faculty of Medicine students with HIV / AIDS (PLWHA). This research uses a quantitative approach using descriptive research design with cross sectional design on 102 respondents selected by non-probability sampling, namely accidental sampling. The univariate results of this study indicate that the majority of FK Unud students are at the level of negative perception that is equal to $52.94 \%$. Then, the variable with a greater proportion has a good perception, namely male gender, public health study program, eighth semester, students who have interacted with PLWHA, students who have participated in organizations related to PLWHA, and students who have good interaction status. It was also found that semester level and interaction intensity had a significant relationship with students' perceptions of PLWHA. Therefore, it is suggested that the Faculty and the Study Program provide a program to increase the knowledge of FK students about HIV / AIDS by integrating it into student events to be able to improve students' perceptions of patients, especially PLWHA.
\end{abstract}

Key Words: Perception, PLWHA, Medical Faculty Students 


\section{PENDAHULUAN}

HIV atau Human Immunodeficiency Virus merupakan suatu virus yang menyerang, merusak bahkan menginfeksi sel darah putih yang mengakibatkan turunnya imunitas tubuh manusia. AIDS atau Acquired Immune Deficiency Syndrome adalah sekumpulan gejala penyakit yang timbul karena turunnya kekebalan tubuh yang disebabkan oleh infeksi HIV (Kemenkes RI, 2014).

Data tahun 2018 melaporkan bahwa penduduk dunia yang hidup dengan HIV sebanyakan 37.9 juta orang yang mana bertambah 1 juta orang dari data UNAIDS tahun 2017, kemudian kasus baru HIV sebanyak 1.7 juta orang, sedangkan, kematian terkait AIDS sebanyak 770.000 orang (UNAIDS, 2019). Data tahun 2018 dari UNAIDS melaporkan bahwa penduduk Indonesia yang hidup dengan HIV sebanyak 620.000 orang, kasus baru sebanyak 46.000 orang, ini merupakan angka terbesar ketiga se-Wilayah Asia Pasifik,sedangkan, kematian terkait AIDS sebanyak 38.000 orang (UNAIDS, 2019).

Data Kementerian Kesehatan menunjukan bahwa dari tahun ke tahun kasus HIV yang terlaporkan cenderung meningkat dan pada tahun 2018 tercatat sebanyak 46.659 kasus HIV dan 10.190 kasus AIDS. Angka kematian terkait AIDS di Indonesia pada tahun 2018 meningkat 58\% dari tahun 2010, yakni dari 24.000 menjadi 38.000 kasus (Kemenkes RI, 2019). Di provinsi Bali angka kasus HIV/AIDS tahun 2019 sebanyak 1.563 kasus meningkat dari tahun 2013 yang sebanyak 1.486 kasus. Bali telah digolongkan sebagai provinsi dengan tingkat epidemi terkonsentrasi (Concentrated Level Epidemic) yang ditunjukan dengan adanya prevalensi lebih dari 5\% pada subpopulasi tertentu seperti pekerja seks, pengguna jarum suntik, tetapi kasus HIV/AIDS pada ibu hamil kurang dari 1\% (Dinkes Provinsi Bali, 2019).

Pemerintah di seluruh dunia termasuk Indonesia telah berkomitmen untuk menghentikan epidemik HIV/AIDS pada tahun 2030. Untuk memenuhi komitmen tersebut, maka pemerintah menetapkan di tahun 2027 akan mencapai target 90-90-90, (90\% ODHA mengetahui status HIV-nya, 90\% yang tahu status masih mendapat ARV, dan 90\% yang masih mendapat ARV virusnya tersupresi). Kemenkes RI melaporkan, hingga September 2019 hanya $57 \%$ atau 363.526 orang yang mengetahui dirinya mengidap HIV, 19\% atau 121.927 ODHA memeroleh pengobatan ARV, kemudian hanya $1 \%$ atau 5.170 yang mendapatkan ARV virusnya tersupresi. Pencapaian Indonesia pada tahun 2019 tersebut masih jauh dari target nasional yaitu 90-90-90. Tujuan program pengendalian HIV-AIDS dan PIMS (Penyakit Infeksi Menular Seksual) adalah untuk "Getting Three Zeroes" sampai tahun 2030.Salah satu isi dari Three Zeroes adalah menurunkan stigma dan diskriminasi.

Persepsi merupakan pandangan yang dimiliki oleh individu, persepsi yang dimiliki oleh masyarakat maupun mahasiswa dapat dibentuk dari dua faktor persepsi yaitu persepsi kerentanan dan persepsi penerimaan. Persepsi negatif 
terhadap ODHA dapat berpengaruh terhadap sikap dan penerimaan terhadap ODHA. Jika persepsi negatif ini dimiliki oleh petugas kesehatan akan dapat berpengaruh terhadap kualitas layanan pada ODHA dan pada akhirnya mempengaruhi kualitas hidup ODHA. Kondisi ini dapat mempengaruhi kepatuhan terapi pada ODHA maupun penderita HIV, sehingga meningkatkan risiko penularan (Afiani, 2017). Hasil penelitiannya menunjukan bahwa adanya hubungan yang signifikan antara persepsi kurang atau stigma dengan kualitas hidup ODHA (Handayani \& Sari, 2017). Stigma terhadap ODHA disebabkan salah satunya karena terdapat persepsi negatif tentang HIV/AIDS, serta peran yang kurang mendukung dari keluarga, teman, guru, tenaga kesehatan, pemerintah maupun tokoh masyarakat. Gifford dalam Ariyanti (2005) menyebutkan bahwa persepsi dapat dilihat melalui beberapa faktor yaitu: faktor budaya dan faktor lingkungan. Faktor lingkungan yang dimaksud yaitu : intensitas berinteraksi dengan ODHA, keikutsertaan dalam organisasi/komunitas terkait ODHA, status interkasi.

Mahasiswa kesehatan merupakan calon tenaga kesehatan yang akan menjadi bagian dari petugas kesehatan, yang akan melakukan kontak dan berperan dalam memberikan dukungan sosial kepada pasien, termasuk pasien ODHA. Pengetahuan dan kompetensi yang mumpuni terkait penyakit yang diderita pasien merupakan bekal mahasiswa kesehatan dalam memberikan pelayanan kesehatan nantinya. Persepsi mahasiswa kesehatan terhadap ODHA dapat menjadi gambaran bagaimana pengetahuan maupun informasi yang diperoleh mahasiswa kesehatan terkait permasalahan HIV/AIDS (Salsabila \& Khoiriyah, 2019).

\section{Menurut Kamus Besar Bahasa} Indonesia stigma merupakan ciri negatif yang tertanam pada individu karena pengaruh lingkungan. Stigma dapat muncul tindakan diskriminasi, yaitu tindakan yang tidak mengakui hak-hak individu lain atau kelompok sebagaimana mestinya manusia yang bermartabat (Kemenkes RI, 2012). Stigma ini dapat muncul karena persepsi yang salah tentang ODHA, persepsi dapat dilihat melalui beberapa faktor-faktor yang mempengaruhi seperti cultural effect (Budaya) dan physical effect (lingkungan) yang menggambarkan situasi kondisi di lingkungan sekitar dan budaya yang berkembang di masyarakat. Stigma oleh tenaga kesehatan bertentangan dengan dasar pertimbangan pengesahan Undang-Undang Nomor 36 Tahun 2014 Tentang Tenaga Kesehatan yang mana tenaga kesehatan memiliki peranan penting untuk meningkatkan kualitas pelayanan kesehatan yang maksimal kepada masyarakat supaya masyarakat mampu untuk meningkatkan kesadaran, kemauan serta kemampuan hidup sehat. Begitu pula dengan mahasiswa kesehatan yang merupakan calon tenaga kesehatan yang seharusnya memahami peranan penting dari tenaga kesehatan. Oleh karena itu, peneliti tertarik mengetahui persepsi mahasiswa Fakultas Kedokteran Universitas Udayana terhadap Orang Dengan HIV/AIDS (ODHA). 
METODE PENELITIAN

Penelitian ini menggunakan pendekatan kuantitatif dengan menggunakan design penelitian deskriptif dengan rancangan cross sectional pada 102 responden yang dipilih secara non-probability sampling yaitu accidental sampling. Sampel penelitian terdiri dari program studi kesehatan masyarakat, pendidikan dokter, dan ilmu keperawatan dari semester empat sampai semester delapan. Penelitian dilaksanakan pada Maret - Juni 2020 di Fakultas Kedokteran Universitas Udayana.
Pengumpulan data dilakukan secara online dengan mengirimkan kuesioner ke grup sosial media dari ketiga program studi. Penelitian ini dianalisis dengan menggunakan analisis univariat dan bivariat dengan melakukan tabulasi silang dan uji statistik yaitu uji chi-square. Variabel dalam penelitian ini adalah jenis kelamin, semester, program studi, intensitas berinteraksi dengan ODHA, keikutsertaan organisasi/komunitas terkait ODHA, dan status interaksi.

HASIL

Analisis Univariat Karakteristik

Responden

Tabel 1. Gambaran Karakteristik Responden

\begin{tabular}{lll}
\hline Variabel & Frekuensi & Persen $(\%)$ \\
\hline Jenis Kelamin & 32 & 31,37 \\
Laki-laki & 70 & 68,63 \\
Perempuan & & \\
Program Studi & 24 & 23,53 \\
Kesehatan Masyarakat & 57 & 55,88 \\
Pendidikan Dokter & 21 & 20,59 \\
Ilmu Keperawatan & & \\
Semester & 34 & 33,33 \\
Delapan & 36 & 35,29 \\
Enam & 32 & 31,37 \\
Empat & &
\end{tabular}

Berdasarkan tabel di atas, dapat dijelaskan bahwa jenis kelamin responden yaitu perempuan berjumlah 70 orang (68,63\%), laki-laki berjumlah 32 orang (31,37\%). Sebanyak 24 orang $(23,53 \%)$ dari mahasiswa kesehatan masyarakat, sebanyak
57 orang $(55,88 \%)$ dari mahasiswa pendidikan dokter, dan sebanyak 21 orang (20,59\%) dari mahasiswa ilmu keperawatan, pembagian jumlah responden masingmasing program studi ini berdasarkan perhitungan proporsional jumlah 
keseluruhan masing-masing mahasiswa di tiap program studi. Dari 102 responden, sebanyak 34 orang $(33,33 \%)$ semester delapan, sebanyak 36 orang (35,29\%)

\section{Analisis Univariat Faktor Lingkungan}

Berikut merupakan data faktor lingkungan responden.

semester enam, dan sebanyak 32 orang

$(31,37 \%)$ semester empat.

Tabel 2. Gambaran Faktor Lingkungan Responden

\begin{tabular}{lll}
\hline Variabel & Frekuensi & Persen (\%) \\
\hline Interaksi dengan ODHA & 58 & \\
Intens & 44 & 56,86 \\
Tidak & & 43,14 \\
Keikutsertaan Organisasi & 47 & \\
Ya & 55 & 46,08 \\
Tidak & & 53,92 \\
Status Interaksi & 62 & \\
Baik & 40 & 60,78 \\
Kurang & & 39,22 \\
\hline
\end{tabular}

Hasil penelitian menunjukan bahwa dari 102 responden, terdapat 58 orang $(56,86 \%)$ yang pernah kontak atau berinteraksi dengan ODHA, dan sebanyak 44 orang $(43,14 \%)$ tidak pernah kontak atau berinteraksi dengan ODHA. Responden yang diketahui pernah atau sedang mengikuti organisasi yang berkaitan dengan ODHA yaitu sebanyak 47 orang (46,08\%),

\section{Persepsi Penerimaan Mahasiswa Fakultas Kedokteran Universitas Udayana terhadap ODHA}

Tabel 3. Persepsi Penerimaan Mahasiswa terhadap ODHA dan sebanyak 55 orang (53,92\%) tidak pernah mengikuti organisasi terkait ODHA. Tabel diatas juga menunjukan bahwa sebanyak 62 orang $(60,78 \%)$ mahasiswa menunjukan bahwa status interaksinya baik dengan ODHA, sedangkan sebanyak 40 orang (39,22\%) mahasiswa yang menunjukan status interaksinya kurang.

\begin{tabular}{ccc}
\hline $\begin{array}{c}\text { Persepsi } \\
\text { Penerimaan }\end{array}$ & f & \% \\
\hline Positif & 42 & 41,18 \\
Negatif & 60 & 58,82 \\
Total & $\mathbf{1 0 2}$ & $\mathbf{1 0 0}$ \\
\hline
\end{tabular}

Hasil penelitian menunjukan bahwa persepsi penerimaan mahasiswa Fakultas 
Kedokteran Universitas Udayana terhadap ODHA berada pada tingkat Persepsi negatif

Persepsi Kerentanan Mahasiswa Fakultas Kedokteran Universitas Udayana terhadap ODHA

Tabel 4. Persepsi Kerentanan terhadap ODHA

Hasil penelitian menunjukan bahwa sebanyak 62 orang $(60,78 \%)$ mahasiswa yang memiliki persepsi kerentanan tinggi. Sedangkan, 40 orang $(39,22 \%)$ yang memiliki persepsi kerentanan yang rendah. Hal ini

Persepsi Mahasiswa Fakultas Kedokteran Universitas Udayana terhadap ODHA

Tabel 5. Persepsi Mahasiswa terhadap ODHA

Hasil penelitian menunjukan bahwa persepsi mahasiswa Fakultas Kedokteran Universitas Udayana terhadap ODHA yakni 60 orang $(58,82 \%)$, dan Persepsi positif sebanyak 42 orang $(41,18 \%)$.

\begin{tabular}{ccc}
\hline $\begin{array}{c}\text { Persepsi } \\
\text { Kerentanan }\end{array}$ & f & \% \\
\hline Tinggi & 62 & 60,78 \\
Rendah & 40 & 39,22 \\
Total & $\mathbf{1 0 2}$ & $\mathbf{1 0 0 , 0 0}$ \\
\hline
\end{tabular}

berarti ada sebesar 60,78\% mahasiswa fakultas kedokteran yang merasa mudah tertular HIV/AIDS apabila berinteraksi dengan ODHA.

\begin{tabular}{ccc}
\hline Persepsi & f & \% \\
\hline Positif & 48 & 47,06 \\
Negatif & 54 & 52,94 \\
Total & $\mathbf{1 0 2}$ & $\mathbf{1 0 0}$ \\
\hline
\end{tabular}

berada pada tingkat Persepsi negatif yakni sebesar 52,94\%, dan Persepsi positif sebesar $47,06 \%$.

Analisis Bivariat Karakteristik dan Faktor Lingkungan dengan Persepsi Penerimaan Mahasiswa FK Unud terhadap ODHA.

Tabel 6. Distribusi Karakteristik dan Faktor Lingkungan dengan Persepsi Penerimaan Mahasiswa FK Unud terhadap ODHA

\begin{tabular}{lllll}
\hline \multirow{2}{*}{ Variabel } & \multicolumn{2}{l}{ Persepsi Penerimaan Terhadap ODHA } & \multirow{2}{*}{ P Value } \\
\cline { 2 - 3 } & \multicolumn{1}{l}{ Positif } & Negatif & Total & \\
\hline $\begin{array}{l}\text { Jenis Kelamin } \\
\quad \text { Laki-Laki }\end{array}$ & $12(37,50 \%)$ & $20(62,50 \%)$ & $32(100 \%)$ & \\
$\quad \begin{array}{l}\text { Perempuan } \\
\text { Program Studi }\end{array}$ & $30(42,86 \%)$ & $40(57,14 \%)$ & $70(100 \%)$ & \\
$\quad$ Kesehatan Masyarakat & $13(54,17 \%)$ & $11(45,83 \%)$ & $24(100 \%)$ & \\
$\quad \begin{array}{l}\text { Pendidikan Dokter } \\
\text { Ilmu Keperawatan }\end{array}$ & $19(33,33 \%)$ & $38(66,67 \%)$ & $57(100 \%)$ & \\
Semester & $10(47,62 \%)$ & $11(52,38 \%)$ & $21(100 \%)$ & \\
$\quad$ Delapan & & & & 0,06
\end{tabular}


Enam
Empat
teraksi dengan ODHA

Intens

Tidak

Keikutsertaan Organisasi

Ikut

Tidak

Status Interaksi

Baik

Kurang

$\begin{array}{lll}16(44,44 \%) & 20(55,56 \%) & 36(100 \%) \\ 8(25 \%) & 24(75 \%) & 32(100 \%)\end{array}$

0,39

$26(44,83 \%) \quad 32(55,17 \%) \quad 58(100 \%)$

$16(36,36 \%) \quad 28(63,64 \%) \quad 44(100 \%)$

0,28

$22(46,81 \%) \quad 25(53,19 \%) \quad 47(100 \%)$

$20(36,36 \%) \quad 35(63,64 \%) \quad 55(100 \%)$

$29(46,77 \%) \quad 33(53,23 \%) \quad 62(100 \%)$

$13(32,50 \%) \quad 27(67,50 \%) \quad 40(100 \%)$
Tabel diatas menunjukan bahwa, berdasarkan karakteristik responden yang berjenis kelamin perempuan lebih dominan memiliki persepsi penerimaan yang positif yaitu sebesar 42.86\%, sedangkan jenis kelamin laki-laki sebesar $37.50 \%$. Berdasarkan program studi, kesehatan masyarakat lebih banyak memiliki Persepsi positif yaitu $54.17 \%$, ilmu keperawatan $47.62 \%$, dan pendidikan dokter $33.33 \%$. Dilihat dari semester, semester delapan lebih banyak memiliki persepsi penerimaan positif yaitu sebesar $52.94 \%$, semester enam sebesar $44.44 \%$, dan semester empat sebesar $25.00 \%$.

Berdasarkan faktor lingkungan, responden yang intens berinteraksi dengan ODHA lebih banyak memiliki persepsi penerimaan positif yaitu sebesar $44.83 \%$, sedangkan yang tidak pernah berinteraksi sebesar 36.36\%. Menurut keikutsertaan organisasi, yang pernah mengikuti organisasi terkait ODHA lebih banyak memiliki persepsi penerimaan positif yaitu $46,81 \%$ sedangkan yang tidak ikut organisasi sebesar 36,36\%. Dilihat dari status interaksi, yang berstatus interaksi baik lebih banyak memiliki persepsi penerimaan positif yaitu $46.77 \%$, sedangkan yang statusnya kurang sebesar $32.50 \%$.

Dari hasil uji statististik, didapatkan bahwa baik karakteristik responden maupun faktor lingkungan memiliki $\mathrm{p}$ value $>0,05$, hal ini menunjukan tidak ada hubungan yang signifikan antara karakteristik responden maupun faktor lingkungan dengan persepsi penerimaan mahasiswa terhadap ODHA. 
Analisis Bivariat Karakteristik dan Faktor Lingkungan dengan Persepsi Kerentanan Mahasiswa FK Unud terhadap ODHA

Tabel 7. Distribusi Karakteristik dan Faktor Lingkungan dengan Persepsi Kerentanan Mahasiswa FK Unud terhadap ODHA

\begin{tabular}{|c|c|c|c|c|}
\hline \multirow{2}{*}{ Variabel } & \multicolumn{3}{|c|}{ Persepsi Kerentanan Terhadap ODHA } & \multirow{2}{*}{ P Value } \\
\hline & Rendah & Tinggi & Total & \\
\hline Jenis Kelamin & & & & 0,13 \\
\hline Laki-Laki & $16(50 \%)$ & $16(50 \%)$ & $31(100 \%)$ & \\
\hline Perempuan & $24(34,29 \%)$ & $46(65,71 \%)$ & $70(100 \%)$ & \\
\hline Program Studi & & & & 0,68 \\
\hline Kesehatan Masyarakat & $11(45,83 \%)$ & $13(54,17 \%)$ & $24(100 \%)$ & \\
\hline Pendidikan Dokter & $22(38,60 \%)$ & $35(61,40 \%)$ & $57(100 \%)$ & \\
\hline Ilmu Keperawatan & $7(33,33 \%)$ & $14(66,67 \%)$ & $21(100 \%)$ & \\
\hline Semester & & & & 0,95 \\
\hline Delapan & $14(41,18 \%)$ & $20(58,82 \%)$ & $34(100 \%)$ & \\
\hline Enam & $14(38,86 \%)$ & $22(61,11 \%)$ & $36(100 \%)$ & \\
\hline Empat & $12(37,50 \%)$ & $20(62,50 \%)$ & $32(100 \%)$ & \\
\hline Interaksi dengan ODHA & & & & 0,36 \\
\hline Intens & $25(43,10 \%)$ & $33(56,90 \%)$ & $58(100 \%)$ & \\
\hline Tidak & $15(34,09 \%)$ & $29(65,91 \%)$ & $44(100 \%)$ & \\
\hline Keikutsertaan Organisasi & & & & 0,52 \\
\hline Ikut & $20(42,55 \%)$ & $27(57,45 \%)$ & $47(100 \%)$ & \\
\hline Tidak & $20(36,36 \%)$ & $35(63,64 \%)$ & $55(100 \%)$ & \\
\hline Status Interaksi & & & & 0,48 \\
\hline Baik & $26(41,94 \%)$ & $36(58,06 \%)$ & $62(100 \%)$ & \\
\hline Kurang & $14(35 \%)$ & $26(65 \%)$ & $40(100 \%)$ & \\
\hline
\end{tabular}

Tabel diatas dapat dilihat bahwa, berdasarkan karakteristik responden yang berjenis kelamin perempuan lebih merasa rentan yaitu sebesar $65,71 \%$, sedangkan jenis kelamin laki-laki sebesar 50\%. Berdasarkan program studi, program studi ilmu keperawatan lebih merasa rentan yaitu sebesar $66,67 \%$, pendidikan dokter sebesar $61,40 \%$ dan kesehatan masyarakat sebesar $54,17 \%$. Dilihat dari semester, semester empat lebih rentan tertular yaitu sebesar $62,50 \%$, semester enam sebesar $61,11 \%$, dan semester delapan sebesar 58,82\%.

Berdasarkan faktor lingkungan, responden yang tidak pernah berinteraksi dengan ODHA lebih merasa rentan yaitu sebesar 65,91\%, sedangkan yang intens berinteraksi sebesar 56,90\%. Menurut keikutsertaan organisasi, yang tidak pernah mengikuti organisasi terkait ODHA lebih 
merasa rentan yaitu 63,64\% sedangkan yang ikut organisasi sebesar 57,45\%. Dilihat dari status interaksi, yang berstatus interaksi kurang lebih merasa rentan yaitu 67,35\%, sedangkan yang statusnya baik sebesar $54,72 \%$.
Dari hasil uji statististik, didapatkan bahwa baik karakteristik responden maupun faktor lingkungan memiliki $\mathrm{p}$ value $>0,05$, hal ini berarti tidak ada hubungan yang signifikan antara karakteristik responden maupun faktor lingkungan dengan persepsi kerentanan mahasiswa.

Analisis Bivariat Karakteristik dan Faktor Lingkungan dengan Persepsi Mahasiswa FK Unud terhadap ODHA

Tabel 8. Distribusi Karakteristik dan Faktor Lingkungan dengan Persepsi Mahasiswa FK Unud terhadap ODHA

\begin{tabular}{lllll}
\hline \multirow{2}{*}{ Variabel } & \multicolumn{2}{l}{ Persepsi Terhadap ODHA } & \multirow{2}{*}{ P Value } \\
\cline { 2 - 4 } Jenis Kelamin & Positif & Negatif & Total & \\
$\quad$ Laki-Laki & & & & \\
$\quad$ Perempuan & $18(56,25 \%)$ & $14(43,75 \%)$ & $32(100 \%)$ & \\
Program Studi & $30(42,86 \%)$ & $40(57,14 \%)$ & $70(100 \%)$ & \\
$\quad$ Kesehatan Masyarakat & $16(66,67 \%)$ & $8(33,33 \%)$ & $24(100 \%)$ & \\
$\quad$ Pendidikan Dokter & $24(42,11 \%)$ & $33(57,89 \%)$ & $57(100 \%)$ & \\
$\quad$ Ilmu Keperawatan & $8(38,10 \%)$ & $13(61,90 \%)$ & $21(100 \%)$ & \\
Semester & & & & 0,04 \\
$\quad$ Delapan & $21(61,76 \%)$ & $13(38,24 \%)$ & $34(100 \%)$ & \\
$\quad$ Enam & $17(47,22 \%)$ & $19(52,78 \%)$ & $36(100 \%)$ & \\
$\quad$ Empat & $10(31,25 \%)$ & $22(68,75 \%)$ & $32(100 \%)$ & \\
Interaksi dengan ODHA & & & & 0,05 \\
$\quad$ Intens & $32(55,17 \%)$ & $26(44,83 \%)$ & $58(100 \%)$ & \\
$\quad$ Tidak & $16(36,36 \%)$ & $28(63,64 \%)$ & $44(100 \%)$ & \\
Keikutsertaan Organisasi & & & & 0,25 \\
$\quad$ Ikut & $25(53,19 \%)$ & $22(46,81 \%)$ & $47(100 \%)$ & \\
$\quad$ Tidak & $23(41,82 \%)$ & $32(58,18 \%)$ & $55(100 \%)$ & \\
Status Interaksi & & & & \\
$\quad$ Baik & $33(53,23 \%)$ & $29(46,77 \%)$ & $62(100 \%)$ & \\
$\quad$ Kurang & $15(37,50 \%)$ & $25(62,50 \%)$ & $40(100 \%)$ & \\
\hline
\end{tabular}


Tabel diatas menunjukan bahwa, berdasarkan karakteristik responden yang berjenis kelamin laki-laki lebih banyak memiliki Persepsi positif yang yaitu sebesar $56.25 \%$, sedangkan jenis kelamin perempuan sebesar $42.86 \%$. Berdasarkan program studi, program studi kesehatan masyarakat lebih banyak memiliki Persepsi positif yaitu sebesar $66.67 \%$, pendidikan dokter sebesar $42.11 \%$ dan ilmu keperawatan sebesar $38.10 \%$. Dilihat dari semester, semester delapan lebih banyak memiliki Persepsi positif yaitu sebesar $61.76 \%$, semester enam sebesar $47.22 \%$, dan semester empat sebesar $31.25 \%$.

Berdasarkan faktor lingkungan, responden yang intens berinteraksi dengan ODHA lebih banyak memiliki Persepsi positif yaitu sebesar $55,17 \%$, sedangkan yang tidak pernah berinteraksi sebesar 36,36\%. Menurut keikutsertaan organisasi, yang pernah mengikuti organisasi terkait ODHA lebih banyak memiliki Persepsi positif yaitu $52,38 \%$ sedangkan yang tidak ikut organisasi sebesar 45,68\%. Dilihat dari status interaksi, yang berstatus interaksi baik lebih banyak memiliki Persepsi positif yaitu 53,23\%, sedangkan yang statusnya kurang sebesar $37,50 \%$.

Dari hasil uji statististik, didapatkan bahwa variabel semester dan interaksi dengan ODHA nilai $\mathrm{p}$ valuenya $\leq 0,05$, hal ini menunjukan adanya hubungan yang signifikan antara karakteristik responden maupun faktor lingkungan dengan persepsi kerentanan mahasiswa.

\section{DISKUSI}

\section{Persepsi Mahasiswa Fakultas Kedokteran Universitas Udayana terhadap Orang dengan HIV/AIDS (ODHA)}

Persepsi mahasiswa Fakultas

Kedokteran Universitas Udayana terhadap ODHA sebagian besar memiliki persepsi yang negatif terhadap ODHA baik persepsi keseluruhan sebesar 52,94\% dan persepsi penerimaan sebesar 58,82\%. Sebagian besar mahasiswa juga merasa lebih rentan yaitu sebesar 60,78\%. Dari sebagian kecil mahasiswa yang persepsinya positif, berdasarkan karakteristik sebagian besar proporsi yang memiliki Persepsi positif yaitu jenis kelamin laki-laki 56,25\% berbanding $42.86 \%$, semester delapan sebesar $61.76 \%$ berbanding semester enam 47.22\%, dan semester empat $31.25 \%$. Hal ini disebabkan karena mahasiswa semester delapan sudah lebih lama menempuh pendidikan, serta lebih sering untuk melakukan studi dilapangan, semester delapan telah melewati masa KKN, magang atau praktek kerja lapangan sehingga cenderung lebih banyak informasi yang diperoleh dibandingkan dengan semester enam dan semester empat. Kemudian dari segi program studi yang proporsi persepsinya positif yaitu kesehatan masyarakat $66.67 \%$ berbanding pendidikan dokter $42.11 \%$ dan ilmu keperawatan $38.10 \%$, hal ini disebabkan karena kesehatan masyarakat lebih menekankan pada upaya pencegahan terhadap penyakit termasuk HIV/AIDS sehingga banyak informasi terkait bagaimana transmisi HIV/AIDS, apa upaya pencegahannya. Berdasarkan faktor lingkungan sebagian besar proporsi yang memiliki Persepsi positif yaitu mahasiswa 
yang intens berinteraksi dengan ODHA $55.17 \%$ berbanding $36.36 \%$, mahasiswa yang mengikuti organisasi $52.38 \%$ berbanding $33,33 \%$, kemudian mahasiswa yang status interaksinya baik $53.23 \%$ berbanding $37.50 \%$. Berdasarkan sebagian kecil mahasiswa yang memiliki persepsi penerimaan positif, dilihat dari karakteristik proporsi yang memiliki persepsi penerimaan yang positif yaitu jenis kelamin perempuan $42.86 \%$ berbanding $37.50 \%$, semester delapan $52.94 \%$ berbanding semester enam $44.44 \%$, semester empat 25\%, untuk program proporsi yang lebih besar memiliki penerimaan yang positif yaitu kesehatan masyarakat sebesar $54.17 \%$ dibandingkan ilmu keperawatan 47,62, pendidikan dokter $33,33 \%$. Ditinjau dari faktor lingkungan, sebagian besar proporsi yang memiliki persepsi penerimaan yang positif yaitu mahasiswa yang intens berinteraksi dengan ODHA $44.83 \%$ berbanding 36,36\%, mahasiswa yang mengikuti organisasi $42.86 \%$ berbanding $40.74 \%$, mahasiswa yang status interaksinya positif $46.77 \%$ berbanding $32.50 \%$.

Dilihat dari persepsi kerentanan tinggi, berdasarkan karakteristik sebagian besar proporsi yang memiliki persepsi kerentanan yang tinggi yaitu jenis kelamin perempuan $65.71 \%$ berbanding $50.00 \%$, semester empat $62.50 \%$ berbanding semester enam $61.11 \%$ dan semester delapan $58.82 \%$, hal ini disebabkan karena semester empat masih beranggapan bahwa pasien ODHA menularkan HIV/AIDS dan tidak memiliki pengalaman lebih sering terjun ke lapangan karena jika dibandingkan dengan semester- semeter lainnya informasi yang diperoleh terkait penyakit menular khususnya HIV/AIDS masih belum sebanyak semestersemeter enam maupun delapan, sehingga merasa rentan tertular HIV/AIDS. Kemudian proporsi persepsi kerentanan tinggi dari program studi yaitu ilmu keperawatan $66.67 \%$ berbanding pendidikan dokter $61.40 \%$, dan kesehatan masyarakat $54.17 \%$. hal ini sebabkan karena ilmu keperawatan lebih intens nantinya berinteraksi dengan pasien tidak terkecuali pasien HIV/AIDS, sehingga merasa rentan tertular. Ditinjau dari faktor lingkungan sebagian besar proporsi yang memiliki persepsi kerentanan yang tinggi yaitu mahasiswa yang tidak pernah berinteraksi dengan ODHA 65.91\% berbanding $56.90 \%$, mahasiswa yang tidak mengikuti organisasi terkait ODHA 64.20\% berbanding $47.62 \%$, kemudian mahasiswa yang status interaksinya kurang $65.00 \%$ berbanding $58.06 \%$.

Penelitian Zahroh dkk., (2014) menjelaskan bahwa persepsi responden terhadap ODHA salah satu faktor yang berpengaruh terhadap munculnya stigma terhadap ODHA. Penelitian Aunana (2019) menyatakan bahwa berdasarkan hasil statistik nilai $\mathrm{p}$ value dari uji Chi Square sebesar $\mathrm{p}=0,00$ yang memiliki arti bahwa ada hubungan persepsi responden dengan stigma masyarakat terhadap ODHA. Penelitian lain oleh Febrianti (2016) menyatakan bahwa persepsi memiliki hubungan yang signifikan dengan stigma remaja terhadap ODHA. Dalam penelitian tersebut juga diungkapkan bahwa persepsi berhubungan sebab akibat dengan stigma 
berat terhadap ODHA. Persepsi negatif terhadap ODHA memiliki pengaruh terhadap stigma pada ODHA sebesar 2,071 yang bermakna bahwa remaja dengan persepsi negatif dua kali beresiko mempunyai stigma berat terhadap ODHA. Persepsi merupakan suatu proses yang mana seseorang menangkap suatu objek dari hasil penginderaannya. Ada dua sumber yang dapat mempengaruhi persepsi individu yakni hal berhubungan dengan segi jasmani atau fisiologi dan sumber lainnya yaitu segi psikologi. Apabila sistem fisiologi terganggu, maka akan dapat mempengaruhi persepsi seseorang (Lilis, 2017).

Salah satu faktor yang mempengaruhi terjadinya stigma pada ODHA yaitu adalah pendidikan. Pendidikan kesehatan memiliki tujuan untuk meingkatkan pengetahuan mengenai HIV/AIDS. Pada penelitian ini ditemukan bahwa tingkatan semester memiliki hubungan yang signifikan dengan persepsi mahasiswa terhadap ODHA dengan nilai $p$ value $\leq 0,05(\mathrm{p}=0,04)$, hal ini berkaitan dengan pengetahuan serta informasi yang dimiliki oleh mahasiswa. Pengetahuan merupakan faktor yang dapat mempengaruhi terjadinya peningkatan Persepsi positif dan pengurangan stigma. Orang yang memiliki pengetahuan cukup tentang faktor risiko, transmisi, pencegahan, serta pengobatan HIV/AIDS cenderung tidak takut serta tidak memberikan Persepsi negatif maupun stigma terhadap ODHA (Zahroh dkk., 2014). Pengetahuan atau informasi tentang HIV/AIDS sangat berpengaruh terhadap sikap individu kepada ODHA. Salah satu penyebab negatifnya persepsi juga karena mis-informasi mengenai bagaimana HIV ditransmisikan (Tri, Ardini, \& A, 2013).

Jenis kelamin tidak memiliki hubungan yang signifikan dengan persepsi dengan nilai $\mathrm{p}$ value sebesar 0,21 . Hal ini karena jenis kelamin tidak secara langsung mempengaruhi persepsi seseorang, namun, jenis kelamin berpengaruh pada salah satu komponen dalam persepsi yaitu komponen afektif atau emosi. Emosi seseorang akan mempengarui persepsi orang tersebut. Lakilaki cenderung dapat mengendalikan emosinya dibandingkan dengan perempuan. Hal ini disebabkan karena perempuan cenderung menggunakan perasaan ketika memberikan respon atau pandangan terhadap sesuatu. Sehingga, menyebabkan perempuan lebih perasa dan lebih berempati terhadap orang lain.

Berdasarkan jenis kelamin, perempuan merasa lebih rentan tertular daripada laki-laki, hal ini dilihat dari sisi biologis dan sosial perempuan. Dilihat dari organ reproduksi perempuan yang memungkinkan menampung sperma yang mengandung virus HIV untuk heteroseksual (Ramadhan, 2013). Dilihat dari sisi sosial, tanggung jawab dan beban perempuan lebih besar untuk membantu orang tua, menyebabkan perempuan seakan tidak punya waktu untuk mengurusi dirinya sendiri termasuk dalam hal kesehatan. Didukung juga dari penelitian Sintha dkk (2012) yang menyatakan bahwa perempuan memiliki kemungkinan tertular IMS-HIV dua kali lebih besar dibandingkan dengan laki-laki. Hal ini disebabkan karena 
kurangnya pengetahuan, disamping itu karena dampak dari perilaku seksual berisiko pasangan, tekanan, serta beban kerja membantu orang tua dikeluarga membatasi akses perempuan baik untuk ke pelayanan kesehatan, memperoleh informasi terkait HIV/AIDS, kemudian karena adanya ketimpangan gender yang mana memposisikan perempuan sebagai korban bahkan pihak yang dipersalahkan, posisi tawar perempuan yang rendah dalam melakukan negosiasi pada setiap hubungan seksual (Sintha dkk., 2012).

Mengikuti organisasi berkaitan dengan ODHA cenderung memiliki pemahaman dan infomasi yang lebih tentang ODHA, disamping itu organisasi yang bergerak dibidang ODHA akan lebih banyak peluang untuk berinteraksi dengan ODHA serta mengenal lebih dekat tentang HIV/AIDS dan ODHA. Hal ini disebabkan karena semakin tinggi pemahaman individu terhadap suatu penyakit maka semakin mengetahui cara penularan dan pencegahan terhadap penyakit, sama halnya dengan HIV/AIDS, semakin tinggi pehamannya maka semakin terbuka untuk berinteraksi dengan ODHA. Namun, pada penelitian ini, didapatkan bahwa keikutsertaan organisasi tidak memiliki hubungan yang signifikan dengan persepsi dengan nilai $\mathrm{p}$ value $>0,05$ $(p=0,25)$. Hal ini karena organisasi akan memberikan dampak apabila melihat lama mengikuti organisasi, apabila mahasiswa yang baru saja bergabung dengan organisasi tentu tidak semua merasakan dampaknya, baik terhadap persepsi, sikap dan perilakunya. Di samping itu, juga dilihat dari keaktifan di organisasi, apakah mahasiswa aktif mengikuti kegiatan organisasi, apakah selalu hadir kegiatan yang diadakan oleh organisasi.

Dalam penelitian ini juga didapatkan bahwa intensitas interaksi dengan ODHA memiliki hubungan yang signifikan dengan persepsi mahasiswa terhadap ODHA dengan nilai $\mathrm{p} \leq 0,05(\mathrm{p}=0,05)$. Berdasarkan penelitian Zahroh (2014) menjelaskan bahwa adanya hubungan yang signifikan antara pemberian stigma HIV/AIDS dengan pengalaman seseorang dalam berinteraksi dengan ODHA (Zahroh dkk., 2014). Pengalaman dan pengetahuan yang dimiliki seseorang mempengaruhi bentuk respon setiap orang terhadap objek yang ada. Begitu pula dengan persepsi, pengalaman seseorang mengikuti organisasi yang berfokus pada HIV/AIDS akan berdampak pada informasi yang dimiliki kemudian merujuk pada persepsinya terhadap HIV/AIDS tersebut (Hati dkk., 2017). Hal ini berarti semakin baik pengalaman orang tersebut tentang HIV/AIDS maka semakin baik pula responnya terhadap ODHA.

Status interaksi berkaitan dengan pengaruh lingkungan sosial terhadap ODHA. Individu yang tidak terpengaruhi lingkungan dalam berinteraksi dengan ODHA cenderung memiliki status interaksi yang baik, sebaliknya yang terpengaruhi lingkungan sosial seperti masyarakat, teman maupun lainnya cenderung memiliki status interaksi yang kurang, hal ini karena individu tidak menggunakan pemikiran, perasaan maupun empatinya sendiri, namun berdasarkan pendapat orang lain. Pada 
penelitian ini didapatkan bahwa status interkasi tidak memiliki hubungan yang signifikan dengan persepsi mahasiswa dengan nilai $p>0,05(p=0,12)$. Menurut Hayati dkk (2014) mengungkapkan bahwa persepsi seseorang dapat ditentukan pada pengalaman hidup, observasi sehari-hari serta pengaruh orang disekitarnya. Kurangnya pemahaman keluarga serta masyarakat mengenai HIV/AIDS akan menimbulkan dampak sosial pada ODHA yang akan mengubah kuantitas serta kualitas berinteraksi maupun kontak dengan keluarga, teman-teman sebaya, keterlibatan dalam masyarakat (Diatmi \& Fridari, 2014). Disinilah peran dari organisasi-organisasi terkait HIV/AIDS seperti yang ada di Universitas Udayana yaitu KMPA (Kelompok Mahasiswa Peduli AIDS), dan KMKP (Kesehatan Masyarakat dan Kedokteran Pencegahan) untuk meningkatkan wawasan serta pengetahuan mahasiswa maupun masyarakat, untuk menyongsong paradigma sehat dengan cara berpikir yang lebih ditekankan pada upayaupaya promotif, preventif, serta protektif. Sehingga, dengan demikian, dapat meningkatkan persepsi positif dari mahasiswa maupun masyarakat terhadap orang yang menderita suatu penyakit khususnya HIV/AIDS.

Menurut Li dkk., (2012) menjelaskan bahwa salah satu hambatan paling besar dalam preventif maupun penanggulangan HIV/AIDS yaitu masih tingginya diskriminasi dan stigma yang dilakukan terhadap ODHA. Penelitian Zahroh dkk (2014) mengungkapkan bahwa sikap keluarga terhadap ODHA adalah faktor yang berpengaruh terhadap munculnya stigma terhadap ODHA.

Stigma serta diskriminasi menjadi hambatan utama pencegahan, perawatan serta pengobatan HIV. Riset menunjukan stigma dan diskriminasi membuat orang enggan mengakses layanan pencegahan maupun pengobatan HIV, hal ini menyebabkan semakin sulit untuk menjangkau mereka karena posisi mereka yang semakin tersembunyi. Stigma maupun diskriminasi ini justru meningkatkan kasus HIV serta meningkatkan kerentanan orang terhadap HIV (Arinta \& Naila, 2017).

Sebaliknya, lingkungan yang kondusif, persepsi yang positif terhadap ODHA akan mendukung upaya penanggulangan HIV. Populasi kunci maupun orang yang rentan tertular, terbuka dengan situasi kerentanan yang mereka hadapi , tingkat akses layanan HIV semakin tinggi, tentu dampaknya penularan HIV dapat dicegah serta ODHA dapat mengkases perawatan, pengobatan, dukungan yang meningkatkan kualitas hidup mereka (Arinta \& Naila, 2017).

\section{SIMPULAN}

Adapun kesimpulan dalam penelitian ini adalah: Persepsi mahasiswa Fakultas Kedokteran Universitas Udayana terhadap Orang Dengan HIV/AIDS (ODHA) sebagian besar negatif yaitu sebesar $52.94 \%$. Ada beda proporsi diantara beberapa variabel pada karakteristik responden yaitu jenis kelamin laki-laki lebih positif persepsinya dari perempuan, semester akhir 
lebih positif persepsinya dari semester awal, program studi kesehatan masyarakat lebih positif persepsinya dari program studi ilmu keperawatan dan pendidikan dokter. Kemudian dari faktor lingkungan, mahasiswa yang intens berinteraksi lebih positif persepsinya dari yang tidak pernah berinteraksi dengan ODHA, yang mengikuti organisasi lebih positif persepsinya dari yang tidak mengikuti organisasi, yang status interaksinya baik lebih positif persepsinya dari yang status interaksinya kurang. Ada hubungan yang signifikan antara variabel tingkatan semester, intensitas interaksi dengan persepsi mahasiswa terhadap ODHA.

\section{SARAN}

Pada penelitian ini menemukan sebagian besar mahasiswa Fakultas Kedokteran Universitas Udayana persepsinya negatif, dan Persepsi negatif yang proporsinya lebih besar ditemukan pada semester awal. Oleh karena itu, temuin ini diharapkan bisa menjadi informasi dan bahan acuan bagi pihak Fakultas maupun Program Studi untuk menyediakan program peningkatan pengetahuan mahasiswa FK tentang HIV/AIDS dengan cara mengintegrasikan ke acara-acara mahasiswa untuk dapat meningkatkan persepsi mahasiswa terhadap pasien khususnya ODHA.

\section{DAFTAR PUSTAKA}

Afiani, M. (2017). Gambaran Stigma HIV/AIDS Pada Mahasiswa Fakultas Kedoktera UGM.
Arinta, D. D., \& Naila, R. Z. (2017). Kajian Hukum dan Kebijakan HIV di Indonesia. (L. Ajeng, \& G. Ricky, Eds.) Jakarta Selatan, Jakarta: Lembaga Bantuan Hukum Masyarakat.

Ariyanti, E. (2005). Pengembangan

Pemanfaatan Polder Kota Lama Semarang Sebagai Ruang Public yang Rekreatif Berdasarkan Persepsi Masyarakat dan Pemerintah. Universitas Diponogoro, Jurusan Perencanaan Wilayah dan Kota.

Aunana, F. (2019). Hubungan Tingkat Pengetahuan dan Persepsi dengan Stigma Masyarakat Terhadap ODHA di Desa Pandowoharja, Kecamatan Sleman, Kabupaten Sleman. Politeknik Kesehatan Kementerian Kesehatan, Program Studi Sarjana Terapan Kebidanan, Yogyakarta.

Diatmi, K., \& Fridari, I. (2014). Hubungan Antara Dukungan Sosial dengan Kualitas Hidup pada Orang Dengan HIV dan AIDS (ODHA) Di Yayasan Spirit Paramacitta. Jurnal Psikologi Udayana, Vol 1 (2): 353-362.

Dinkes Provinsi Bali. (2019). Analisis Situasi Epidemiologi HIV-AIDS Provinsi Bali. Denpasar.

Febrianti. (2016). Faktor-faktor yang Berhubungan dengan Stigma terhadap Orang dengan HIV dan AIDS (ODHA). Jurnal Endurance, 158167.

Handayani, F., \& Sari, F. (2017, November 1). Faktor yang Mempengaruhi Kualitas Hidup Orang Dengan HIV/AIDS 
(ODHA) Di Kota Kupang. Community Medicine and Pubic Health, 33.

Hati, K., Shaluhiyah, Z., \& Suryoputro, A. (2017). Stigma Masyarakat Terhadap ODHA Di Kota Kupang Provinsi NTT. Promosi Kesehatan Indonesia, 6277.

Hayati, Mardhiyah, Sudiana, I. K., \& Kristiawati. (2014). Analisis Faktor Orang Tua Terhadap Status Gizi Balita Pendekatan Teori Health Belief Model. Universitas Erlangga, Fakultas Keperawatan.

Husnul, U., Yulia, I. D., \& Veny, E. (2015, Februari). Identifikasi Karakteristik Orang Risiko Tinggi HIV dan AIDS tentang Program Pelayanan Voluntary Counseling and Testing (VCT). Universitas Riau, Program Studi Ilmu Keperawatan, Riau.

Kemenkes, RI. (2012). Petunjuk Teknis Pemeriksaan Laboratorium untuk Diagnosis Bayi dan Anak di bawah 18 Bulan Terpapar HIV.

Kemenkes RI. (2014). InfoDATIN : Pusat

Data dan Informasi Kementerian Kesehatan RI.

Kemenkes RI. (2019). Profil Kesehatan Indonesia. Jakarta: Kementerian Kesehatan Republik Indonesia.

Lilis, E. (2017). Analisis Faktor yang Berhubungan dengan Persepsi Dewasa Muda HIV dan AIDS dengan Sikap Pencegahan Infeksi Oportunistik di Kelompok Dukungan Sebaya. Universitas Airlangga, Program Studi Pendidikan Ners, Fakultas Keperawatan, Surabaya.
Li, X., Wang, H., He, G., Fennie, K., \& Williams, A. (2012). Shadow on my heart: a culturally grounded concept of HIV stigma among Chinese injection drug users. Journal of the Association of Nurses in AIDS Care, 23(1):52-62.

Ramadhan, H. (2013, Agustus Rabu). Perempuan Lebih Rentan Tertular HIV/AIDS. Jurnal Perempuan.

Salsabila, M. P., \& Khoiriyah. (2019). Gambaran Persepsi Mahasiswa Tentang Penularan Penyakit HIV/AIDS Di Universitas Muhammadiyah Semarang. Univesitas Muhammadiyah Semarang. Semarang: Prosiding Mahasiswa Seminar Nasional Unimus.

Sintha Kurnia Dewi, D. M., Lila Wulandari, L. P., \& Wirawan, D. (2012). Determinan Sosial Kerentanan Perempuan Terhadap Penularan IMS dan HIV. Unair, 22-35.

Tri, P., Ardini, S., \& A, I. (2013). Faktor-Faktor yang Mempengaruhi Stigma dan Diskriminasi kepada ODHA (Orang dengan HIVIAIDS) oleh petugas kesehatan. Universitas Padjadjaran, Bandung.

UNAIDS. (2019). UNAIDS DATA 2019. Switzerland.

Zahroh, S., Syamsulhuda, B. M., \& Bagoes, W. (2014, Mei). Stigma Masyarakat terhadap Orang dengan HIV/AIDS. Jurnal Kesehatan Masyarakat Nasional, 9, 333-339. 